CLINICAL STUDY

\title{
Significant GH deficiency after long-term cure by surgery in adult patients with Cushing's disease
}

\author{
Francesca Pecori Giraldi, Massimiliano Andrioli, Laura De Marinis ${ }^{1}$, Antonio Bianchi ${ }^{1}$, Antonella Giampietro ${ }^{1}$, \\ Martina De Martin, Eugenia Sacco ${ }^{1}$, Massimo Scacchi, Alfredo Pontecorvi ${ }^{1}$ and Francesco Cavagnini \\ Chair of Endocrinology, Ospedale San Luca Istituto Auxologico Italiano IRCCS, University of Milan, via Spagnoletto 3, I-20149 Milan, Italy and \\ ${ }^{1}$ Department of Endocrinology, Catholic University School of Medicine, Rome, Italy \\ (Correspondence should be addressed to F Cavagnini; Email: cavagnini@auxologico.it)
}

\begin{abstract}
Objective: Impaired GH secretion usually accompanies Cushing's syndrome and a variable proportion of patients reportedly fail to recover normal GH secretion after successful treatment. This wide variability is most probably due to differences in the treatment (i.e. surgery and/or radiotherapy), timing of patient re-evaluation after surgery and dynamic tests employed to challenge GH secretion, and hinders a precise assessment of risk of GH deficiency after cure. The aim of the present study is to evaluate GH secretory status after long-term cure of Cushing's disease achieved by surgery alone.

Design and methods: We studied 34 patients (27 females and 7 males, age range 21-68 years) formerly affected by Cushing's disease. Patients were studied 2-20 years (median 3.3 years) following remission of hypercortisolism; all patients underwent transsphenoidal surgery with the removal of an ACTHsecreting adenoma; repeat pituitary surgery for relapse was performed in two patients while bilateral adrenalectomy was necessary in two patients. In all subjects, the GH response to GHRH+arginine stimulation was evaluated. At the time of testing, 13 patients were still on steroid replacement therapy. Results: In long-term surgical remission, 22 patients $(65.0 \%)$ presented subnormal GH secretion; partial GH deficiency (GH peak $<16.5 \mu \mathrm{g} / \mathrm{l}$ ) was found in 11 patients and severe $\mathrm{GH}$ deficiency (GH peak $<9 \mu \mathrm{g} / \mathrm{l}$ ) in another 11. Male gender and length of hypercortisolism were risk factors for postsurgical GH deficiency.

Conclusions: This study demonstrates the presence of GH deficiency in a high percentage of patients with Cushing's disease after long-term remission of hypercortisolism obtained by surgery alone. Male gender and length of hypercortisolism are the most significant predictors of postsurgical GH deficiency. This finding is significant as it highlights that even the most favourable therapeutical course, i.e. remission achieved by surgery alone, is accompanied by impaired GH secretion. Assessment of GH secretion is therefore recommended for all patients cured from Cushing's disease, even if not submitted to radiotherapy. Studies on the clinical impact of GH deficiency and the use of GH replacement therapy seem warranted in patients cured from Cushing's disease.
\end{abstract}

European Journal of Endocrinology 156 233-239

\section{Introduction}

Excessive glucocorticoids unquestionably inhibit growth hormone $(\mathrm{GH})$ secretion. Indeed, GH secretion is impaired in both children (1) and adult patients $(2,3)$ with exogenous or endogenous hypercortisolism. In contrast, to what extent recovery of GH secretion follows the normalisation of cortisol concentrations is less well established $(4,5)$. This uncertainty is due to the fact that patients were often tested shortly after remission from hypercortisolism $(6,7)$ and remission was achieved by several treatment modalities, including radiation therapy which is known to progressively impair anterior pituitary function over time (8). Further, patients cured from Cushing's disease frequently do not recover normal weight and this may confound the interpretation of GH status. A high prevalence of GH deficiency has also been reported after pituitary surgery/radiotherapy in paediatric Cushing's disease together with a favourable outcome obtained by early GH replacement $(6,7)$. We currently lack the information on GH secretory status in patients with Cushing's disease treated only by surgery, which in fact is the most frequent therapeutic course. In order to clarify this issue, we studied 34 patients with Cushing's disease after long-term remission obtained with surgery only. We used the GHRH + arginine test as this challenge is unaffected by glucocorticoids and can be evaluated according to the body mass index (BMI) (9). 


\section{Patients and methods}

\section{Patients}

Thirty four patients ( 7 males, 27 females, age $41.2 \pm$ 2.1 years, range 21-68 years) previously affected by Cushing's disease were studied. The diagnosis had been based on the usual diagnostic criteria (10) and confirmed by pathology of the surgical specimen. Two patients presented a macroadenoma and the remainder a microadenoma. Of the 34 patients, 13 were of normal weight $\left(\mathrm{BMI}<25 \mathrm{~kg} / \mathrm{m}^{2}\right), 18$ overweight (BMI $25-30 \mathrm{~kg} / \mathrm{m}^{2}$ ) and 3 obese $\left(\mathrm{BMI}>30 \mathrm{~kg} / \mathrm{m}^{2}\right)$.

Transsphenoidal surgery was performed as the first and only therapeutic approach in 31 patients. Two patients were resubmitted to pituitary surgery, followed by bilateral adrenalectomy in one, due to recurrence of hypercortisolism. One last patient was cured by bilateral adrenalectomy after failure of the first transsphenoidal surgery. The study was approved by both Institutions' Ethical Committees and written informed consent was obtained from all patients. Assessment of GH status was performed at least 2 years $(59.3 \pm 8.57$ months, range 24-261 months) after remission of hypercortisolism by cross-sectional design. At the time of GH testing, all patients presented normal parameters of adrenal function (urinary free cortisol (UFC), serum cortisol levels, normal cortisol suppression by low dose dexamethasone test). Thirteen patients, including the two adrenalectomised patients, were still on steroid replacement therapy (12.5-37.5 mg cortisone acetate or $30 \mathrm{mg}$ hydrocortisone daily). All other patients were off the replacement therapy, since at least 6 months and none were taking drugs known to interfere with adrenal or pituitary secretion. Seven patients were on thyroid replacement therapy for primary hypothyroidism; postsurgical diabetes insipidus requiring desmopressin therapy was present in one patient. Gonadal function was normal in all patients with two men on androgen replacement therapy.

\section{Assessment of GH secretion}

GH was measured after stimulation with growth hormone-releasing hormone $(\mathrm{GHRH})+$ arginine; an indwelling catheter was placed into a forearm vein between 0700 and $0800 \mathrm{~h}$ and continuously flushed with saline. Two baseline samples were collected at least $15 \mathrm{~min}$ apart prior to the injection of $1 \mu \mathrm{g} / \mathrm{kg}$ body weight GHRH (Geref, Industria Farmaceutica Serono, Rome) as an i.v. bolus and infusion of $0.5 \mathrm{~g} / \mathrm{kg}$ body weight (maximal dose $30 \mathrm{~g}$ ) arginine (S.p.A. Laboratorio Farmacologico, Turin) over $30 \mathrm{~min}$ through a separate i.v. access. Blood samples were then collected $15,30,45,60$ and 90 min after the beginning of the infusion. Blood samples were centrifuged at $1000 \boldsymbol{g}$ for $10 \mathrm{~min}$ at $4{ }^{\circ} \mathrm{C}$, serum collected by aspiration and stored at $-20{ }^{\circ} \mathrm{C}$ until assayed for $\mathrm{GH}$. Insulin-like growth factor-I (IGF-I) was measured in the samples collected at baseline. On the day of testing, patients on steroid replacement therapy were administered the drug at the end of the test.

\section{Assays}

Plasma adrenocorticotrophin (ACTH) and serum cortisol were measured by immunometric assay (Liason, Nichols Institute, San Juan Capistrano, CA, USA). UFC was measured by radioimmmunoassay after urine extraction with dichloromethane (Byk-Sangtec Diagnostica, Dietzenbach, Germany). Intra- and interassay coefficients of variations were 3.2 and $8.2 \%$ for ACTH, 3.0 and $4.7 \%$ for serum cortisol respectively and 3.5 and $6.2 \%$ for UFC. Normal ranges are $10-50 \mathrm{pg} / \mathrm{ml}$ for ACTH, $5-25 \mu \mathrm{g} / \mathrm{dl}$ for serum cortisol and 10$80 \mu \mathrm{g} / 24 \mathrm{~h}$ for UFC (11). IGF-I serum concentrations were determined by chemiluminescent immunoassay (CLIA, Nichols Institute, San Juan Capistrano, USA). Sensitivity of the assay is $6 \mu \mathrm{g} / \mathrm{l}$. IGF-I s.D. score (SDS) was calculated according to the formula: (logIGF-I+ $0.00625 \times$ age-2.555)/0.104 (12). IGF-I scores comprised between -2 and $+2 \operatorname{SDS}$ (i.e. $3^{\circ}-97^{\circ}$ centile) are normal. GH serum concentrations were measured by CLIA (Nichols Institute); sensitivity of the assay is $0.01 \mu \mathrm{g} / \mathrm{l}$; baseline values up to $4 \mu \mathrm{g} / \mathrm{l}$ are considered normal.

Peak of GH levels during GHRH + arginine were used to define the response as normal $(\mathrm{GH}>16.5 \mu \mathrm{g} / \mathrm{l})$, partial $\mathrm{GH}$ deficiency $(\mathrm{GH}<16.5 \mu \mathrm{g} / \mathrm{l})$ or severe $\mathrm{GH}$ deficiency $(\mathrm{GH}<9 \mu \mathrm{g} / \mathrm{l})(13)$. Weight-adjusted thresholds for $\mathrm{GH}$ deficiency were also taken into consideration; $\mathrm{GH}$ peak $<11.5 \mu \mathrm{g} / \mathrm{l}$ in normal weight, $<8 \mu \mathrm{g} / \mathrm{l}$ in overweight and $<4.2 \mu \mathrm{g} / \mathrm{l}$ in obese subjects $(9,14)$.

\section{Statistical analysis}

The results obtained were analysed using Student's t-test or Mann-Whitney's test for unpaired data, as appropriate. Bonferroni's correction was used for multiple comparisons. Qualitative differences were established by $\chi^{2}$ or Fisher's exact test, according to the sample size. Linear regression analysis was used to evaluate association between the variables. KaplanMeier survival was calculated using GH deficiency as endpoint and difference among binary variables assessed by log-rank test (Statview, Abacus Concepts, Berkeley, CA, USA). Cox proportional hazard analysis was used to establish predictors of $\mathrm{GH}$ deficiency. Statistical significance was accepted for $P<0.05$. Data are given as mean \pm s.e.m.

\section{Results}

According to established criteria for the GHRH+ arginine test (13), 22 out of $34(65.0 \%)$ patients 
cured from Cushing's disease by pituitary surgery alone had impaired $\mathrm{GH}$ secretion at prolonged follow-up (Fig. 1). Eleven patients (32.5\%) presented partial GH deficiency and an equal number $(32.5 \%)$ severe GH deficiency. The mean of GH peak was $34.5 \pm$ $3.96 \mu \mathrm{g} / \mathrm{l}$ for normal responses, $11.9 \pm 0.59 \mu \mathrm{g} / \mathrm{l}$ for partial GH deficiency and $4.74 \pm 0.83 \mu \mathrm{g} / \mathrm{l}$ for severely $\mathrm{GH}$ deficient patients $(P<0.001$ for normal versus $\mathrm{GH}$ deficient, $P=0.05$ for partial versus severe $\mathrm{GH}$ deficiency). Of note, the two patients operated twice at the pituitary were both severely $\mathrm{GH}$ deficient; the patient with diabetes insipidus was partially $\mathrm{GH}$ deficient and the two adrenalectomised patients were partially and severely $\mathrm{GH}$ deficient respectively. $\mathrm{GH}$ deficiency, both partial and severe, was present in $52.4 \%$ of patients off steroid replacement therapy and in $84.6 \%$ of patients still treated with cortisone acetate/hydrocortisone $(P=0.07)$; severe $\mathrm{GH}$ deficiency was equally prevalent among patients on/off steroids (38.5 vs $28.6 \%$, NS).

$\mathrm{GH}$ peak responses to $\mathrm{GHRH}+$ arginine stimulation were negatively correlated with BMI $(r=-0.385$, $P<0.02)$ and body weight $(r=-0.474, \quad P<0.005)$ even though the body weight of our patients was mostly normal. In fact, evaluation of the GH response using the recently proposed weight-corrected cut-off values for $\mathrm{GH}$ deficiency (9) revealed that 3 out of 13 normal weight patients and 7 out of 18 overweight patients were GH deficient; conversely, all 3 obese patients presented peak GH values $>4.2 \mu \mathrm{g} / \mathrm{l}$. Overall, these results are comparable with the prevalence of severe GH deficiency as assessed by standard criteria (13) and indicate that GH deficiency occurred independently of weight in our patients.

As expected, the $\mathrm{GH}$ response to GHRH+arginine was smaller in male than in female patients $(6.9 \pm 2.77$ vs $20.3 \pm 3.03 \mu \mathrm{g} / \mathrm{l}$ respectively, $P<0.007)$ leading to a greater preponderance of severe $\mathrm{GH}$ deficiency in males (71.5 vs $22.2 \%, P=0.024)$. Of note, BMI was comparable among sexes $(25.0 \pm 2.34$ vs $25.9 \pm$ $5.2 \mathrm{~kg} / \mathrm{m}^{2}$, NS). Partial GH deficiency developed in equal proportion among males and females. No association between GH peak and hypothalamicpituitary-adrenal (HPA) axis parameters (e.g. UFC, serum cortisol, cortisol suppression by low dose dexamethasone, ACTH values in the active phase and at the time of testing) was detected. Further, no significant differences were found for the same variables between partially and severely $\mathrm{GH}$ deficient patients. No association was found between $\mathrm{GH}$ deficiency and prolactin levels. As only two patients presented a macroadenoma, no analysis on the size of the tumour could be performed.

In keeping with the gender difference reported above, male patients presented an increased rate of severe $\mathrm{GH}$ deficiency development at Kaplan-Meier analysis (males versus females $P<0.05$, Fig. 2). Of note, no difference in anthropometric and HPA parameters was observed between male and female patients. Proportional hazard analysis revealed that the only predictor of GH deficiency was the length of hypercortisolism (positive predictor, coefficient $=0.218$, $P<0.005)$. No relationship was found between $\mathrm{GH}$ status and age, BMI, HPA axis parameters in the active phase and at the time of testing at either parametric or conditional logistic regression analysis.

IGF-I scores below -2 S.D. was displayed by 17 patients $(50 \%)$; among them, 3 patients presented normal responses to GHRH + arginine, 8 were partially GH-deficient and 6 presented complete GH deficiency. IGF-I SDS were lower in patients with complete or partial GH deficiency compared with patients with normal GH reserve $(-2.9 \pm 0.68$ and $-2.7 \pm 0.52$ vs $-1.6 \pm 0.31$ SDS respectively, both $P<0.05)$. No difference was observed between IGF-I scores in patients with partial or complete GH deficiency. (Fig. 3). Peak GH levels were significantly correlated with IGF-I SDS $(r=0.37, P<0.05)$; no association was

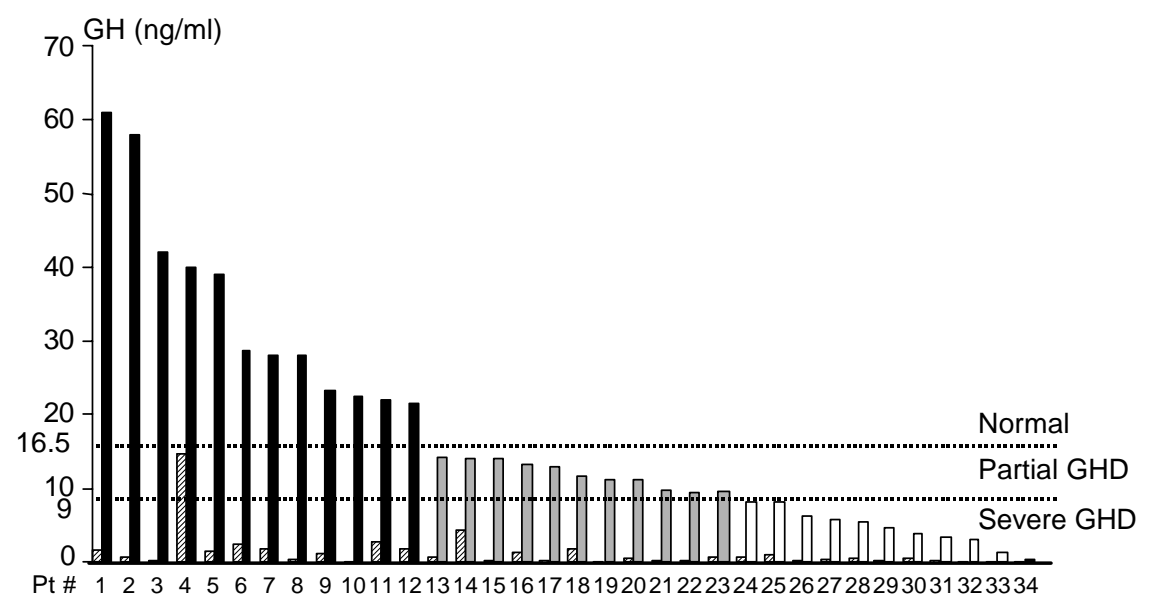

Figure $1 \mathrm{GH}$ response to $\mathrm{GHRH}+$ arginine in individual patients cured from Cushing's disease by surgery alone. Baseline (shaded bar) and peak (black/grey/white bars) GH levels. Dotted lines indicate thresholds for $\mathrm{GH}$ deficiency. 


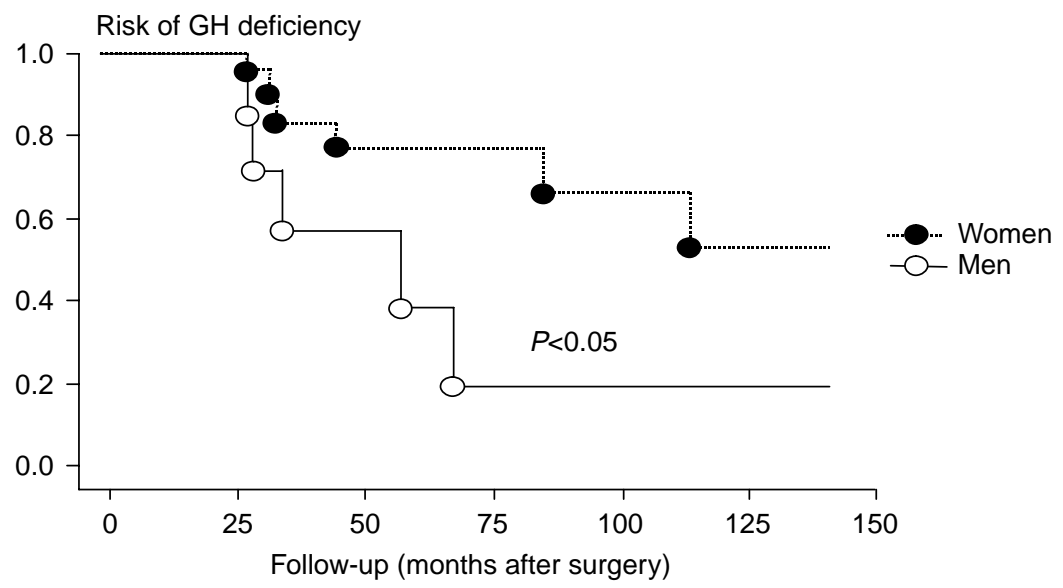

\begin{abstract}
Figure 2 Kaplan-Meier survival plot for risk of severe GH deficiency in patients cured from Cushing's disease by surgery alone subdivided according to sex. Analysis was terminated at 150 months as $<20 \%$ of the initial population was still available to follow-up.
\end{abstract}

observed between IGF-I scores and age, gender, BMI, length of follow-up, replacement therapy or prolactin secretion.

\section{Discussion}

Our study shows that a considerable proportion of patients with Cushing's disease treated by surgery alone displays impaired GH secretion after long-term remission of hypercortisolism. This is a relevant finding as it shows that even the most favourable therapeutical outcome, i.e. remission achieved by surgery alone, is associated with impaired GH secretion. High prevalence of GH deficiency had previously been reported in patients cured from Cushing's syndrome, but the past series contained patients treated by radiation therapy in addition to transsphenoidal surgery (15-20). Radiotherapy carries a considerable risk of causing hypopituitarism (21) and the $\mathrm{GH}$ axis is considered the most vulnerable in this respect, indeed, $\mathrm{GH}$ production may fail before gonadotrophin secretion (21). In other studies, patients had been tested early after resolution of Cushing's disease $(6,7,22,23)$ but the $\mathrm{GH}$ axis has been shown to recover over time $(5,24)$, thus testing after more prolonged follow-up appears necessary. On balance, published studies do not allow a precise estimation of $\mathrm{GH}$ deficiency in patients cured from Cushing's disease, especially in patients in whom surgery was sufficient to obtain remission of disease which, thankfully, is the majority. Our findings now provide this information.

We used a single test, GHRH + arginine stimulation a test which has never before been used in patients cured from Cushing's disease - to assess GH secretory reserve. In fact, a variety of tests had been employed in this context, often even more than one in the same series, adding to the heterogeneity of reported data $(8,19,22,25) . \mathrm{GHRH}+$ arginine testing appears to be a reliable and convenient alternative to insulin tolerance testing (ITT) for the diagnosis of GH deficiency in adults
(26), as it appears unaffected by exogenous steroids (27) and reliable across a large age span (28). The latter is an additional advantage as we evaluated patients ranging from 21 to over 60 years of age. In addition, the response to $\mathrm{GHRH}+$ arginine stimulation can be analysed according to the recently proposed weightadjusted criteria $(9,14)$. Evaluation using the latter as well as standard thresholds yielded superimposable results; in fact, our series comprised mostly overweight and normal weight subjects for whom the recommended cut-offs ( 8.0 and $11.5 \mu \mathrm{g} / \mathrm{l}$ respectively) are close to the standard $9.3 \mu \mathrm{g} / \mathrm{l}$ threshold. Of note, all three our obese patients presented GH responses above $9.3 \mu \mathrm{g} / \mathrm{l}$.

In our series, severe GH deficiency was detected 2 years after the cure of hypercortisolism in one-third of patients $(32.5 \%)$ and an equal number presented partial GH deficiency, totalling 65\%; these results were substantiated by the detection of lower IGF-I SDS in these patients. The length of hypercortisolism and male sex appeared to be the most consistent predictors of postsurgical GH deficiency. The duration of disease has been associated with the persistence of some Cushingoid features after resolution of hypercortisolism, such as

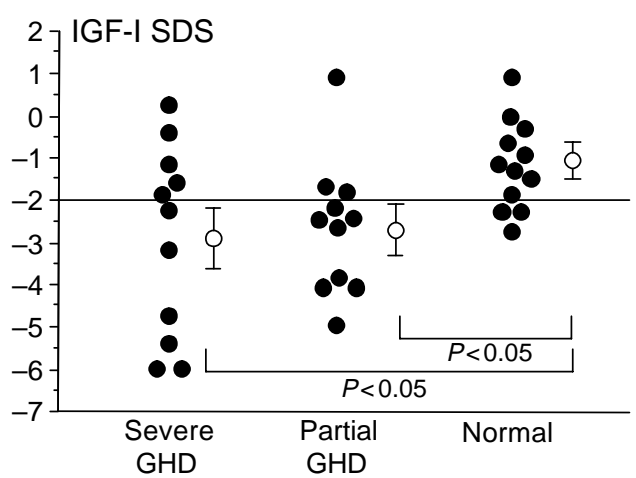

Figure 3 IGF-I S.D. in patients cured from Cushing's disease by surgery alone. Subnormal values are below -2 SDS, hard line. Empty circles indicate mean \pm S.E.M. 
hypertension $(29,30)$, increased carotid artery thickness (31) and obesity (30), thus recovery of somatotroph function may also depend on the length of exposure to excess corticosteroids. As for the greater prevalence of GH deficiency among our male patients, it is noteworthy that lower $\mathrm{GH}$ responses to GHRH+ arginine have been reported in healthy males compared with healthy females, with higher BMI in males contributing to this difference according to some but not all authors $(32,33)$. However, this gender-related difference does not seem to affect the diagnostic cut-offs (32) and the sensitivity of the test and an equal prevalence of GH deficiency was detected among male and female patients tested by both GHRH + arginine and ITT (14). Our observation appears therefore unique to Cushing's disease and is in accordance with the more severe clinical presentation, cortisol hypersecretion and worse postsurgical outcome in adult male patients with active Cushing's disease (34) although the reasons underlying these gender-specific differences are as yet obscure. Somatotroph failure was also slightly more prevalent among patients on glucocorticoid replacement therapy, although this difference fell short of statistical significance. This difference is unlikely to result from the interference of exogenous steroids on $\mathrm{GH}$ secretion as the GHRH + arginine test is reportedly unaffected by administration of steroids at pharmacological dosages $(27,35)$, i.e. far greater than those employed to correct postsurgical hypocortisolism.

Active Cushing's disease is a known condition of GH deficiency although the pathophysiology of this alteration is not completely understood. Prolonged exposure to supraphysiological levels of cortisol has been postulated to impair GH secretion through several mechanisms. Excess glucocorticoids have been hypothesised to reduce GHRH release (36) and/or increase somatostatinergic tone (37) or inhibit $\mathrm{GH}$ secretion by pituitary somatotrophs (38). In fact, spontaneous $24 \mathrm{~h} \mathrm{GH}$ secretion (22) as well as GH responsiveness to L-dopa (22), GHRH + arginine (39) and ITT (5) are impaired in patients with active Cushing's disease. As we and others have shown, GH secretion does not always normalise after cure. Several hypotheses have been put forward to explain the persistence of this defect, including surgical manipulation of the pituitary during the search for small tumours. In fact, in large neurosurgical series, $\mathrm{GH}$ deficiency developed after pituitary surgery in 14-30\% of operated patients and this occurrence was independent of the size of the lesion $(40,41)$. Impaired GH secretion after recovery from hypercortisolism may also likely result from an irreversible damage of the GHRH/ GH axis during the active phase of the disease induced by sustained hypercortisolism, as suggested by comparison of postsurgical GH deficiency among different pituitary tumours (42). We have not tested the $\mathrm{GH}$ axis in these patients prior to surgery and thus cannot compare the GH status before and after surgery. On balance, both surgical and presurgical factors contribute to postsurgical $\mathrm{GH}$ deficiency in patients with Cushing's disease.

The impact of impaired GH secretion after cure of Cushing's disease, even in patients who were not treated by radiation therapy, should not be underestimated. Indeed, GH deficiency impairs catch-up growth in short children cured from Cushing's disease and treatment with $\mathrm{GH}$ has proven greatly beneficial in these patients $(6,7)$. In adults, GH deficiency could contribute to metabolic derangements, increased cardiovascular risk and osteoporosis, which have been observed years after successful resolution of Cushing's disease $(30,31,43)$. Accordingly, a study on a small group of patients has shown that adult patients with Cushing's disease who develop GH deficiency fare worse than age-matched patients with hypopituitarism due to other disorders, both prior to initiating rhGH therapy and during the course of treatment (17). In addition to patients with severe GH deficiency, we observed a considerable proportion of patients cured from Cushing's disease with partial GH deficiency, a condition which is claiming an increasing attention. Indeed, patients who fall in this 'grey area' of impaired GH secretory status have recently been shown, in spite of normal IGF-I scores, to present several metabolic abnormalities and possible progression towards full GH deficiency (44). Thus, patients cured from Cushing's disease merit careful evaluation, both with regard to the benefits of GH treatment in patients with severe GH deficiency and clinical surveillance of patients with partial GH deficiency with low IGF-I SDS.

In conclusion, our study demonstrates the presence of GH deficiency in a high percentage of patients with Cushing's disease even after long-term remission of hypercortisolism obtained only by surgical means. Male gender and length of hypercortisolism appeared to be the most significant predictors of postsurgical GH deficiency. These findings highlight the need for re-evaluation of the GH/IGF-1 axis in all patients cured of Cushing's disease, even if not submitted to radiotherapy, and establish the need for studies on the possible use of $\mathrm{GH}$ replacement therapy in patients cured from Cushing's disease with impaired GH secretion.

\section{References}

1 Styne DM, Grumbach MM, Kaplan SL, Wilson CB \& Conte FA. Treatment of Cushing's disease in childhood and adolescence by transsphenoidal microadenomectomy. New England Journal of Medicine 1984310 889-893.

2 Krieger DT \& Glick SM. Sleep EEG stages and plasma growth hormone concentrations in states of endogenous and exogenous hypercortisolemia or ACTH elevation. Journal of Clinical Endocrinology and Metabolism 197439 986-1000.

3 Smals AE, Pieters GF, Smals AGH, Benraad TJ \& Kloppenborg PWC. Human pancreatic growth hormone-releasing hormone fails to 
stimulate human growth hormone both in Cushing's disease and Cushing's syndrome due to adrenocortical adenoma. Clinical Endocrinology 198624 401-407.

4 Veldman RG, Frölich M, Pincus SM, Veldhuis JD \& Roelfsema F. Apparently complete restoration of normal daily adrenocorticotropin, cortisol, growth hormone and prolactin secretory dynamics in adults with Cushing's disease after clinically successfull transsphenoidal adenomectomy. Journal of Clinical Endocrinology and Metabolism 200085 4039-4046.

5 Tzanela M, Karavitaki N, Stylianidou C, Tsagarakis S \& Thalassinos N. Assessment of GH reserve before and after successful treatment of adult patients with Cushing's syndrome. Clinical Endocrinology 200460 309-314.

6 Davies JH, Storr HL, Davies K, Monson JP, Besser GM, Afshar F, Plowman PN, Grossman AB \& Savage MO. Final adult height and body mass index after cure of paediatric Cushing's disease. Clinical Endocrinology $2005 \mathbf{6 2} 466-472$.

7 Lebrethon MC, Grossman AB, Afshar F, Plowman PN, Besser GM \& Savage MO. Linear growth and final height after treatment for Cushing's disease in childhood. Journal of Clinical Endocrinology and Metabolism 200085 3262-3265.

8 Degerblad M, Brismar K, Rahn T \& Thorén M. The hypothalamuspituitary function after pituitary stereotactic radiosurgery: evaluation of growth hormone deficiency. Journal of Internal Medicine 2003253 454-462.

9 Corneli G, Di Somma C, Balzelli R, Rovere S, Gasco V, Croce CG, Grottoli S, Maccario M, Colao A, Lombardi G, Ghigo E, Camanni F \& Aimaretti G. The cut-off limits of the GH response to GH-releasing hormone-arginine test related to body mass index. European Journal of Endocrinology 2005153 257-264.

10 Invitti C, Pecori Giraldi F, De Martin M, Cavagnini F \& the Study Group of the Italian Society of Endocrinology on the pathophysiology of the hypothalamic-pituitary-adrenal axis. Diagnosis and management of Cushing's syndrome: results of an Italian multicentre study. Journal of Clinical Endocrinology and Metabolism 199984 440-448.

11 Pecori Giraldi F, Scaroni C, Arvat E, De Martin M, Giordano R, Albiger N, Leao AAS, Picu A, Mantero F \& Cavagnini F. Effect of protracted treatment with rosiglitazone, a PPARgamma agonist, in patients with Cushing's disease. Clinical Endocrinology $2006 \mathbf{6 4}$ 219-224.

12 Wallander M, Brismar K, Ohrvik J, Ryden L \& Norhammar A. Insulin-like growth factor I: a predictor of long-term glucose abnormalities in patients with acute myocardial infarction. Diabetologia $2006492247-2255$.

13 Aimaretti G, Corneli G, Razzore P, Bellone S, Baffoni C, Arvat E, Camanni F \& Ghigo E. Comparison between insulin-induced hypoglycemia and growth hormone (GH)-releasing hormone + arginine as provocative tests for the diagnosis of GH deficiency in adults. Journal of Clinical Endocrinology and Metabolism $1998 \mathbf{8 3}$ 1615-1618.

14 Biller BMK, Samuels MH, Zagar A, Cook DM, Arafah BM, Bonert V, Stavrou S, Kleinberg D, Chipman JJ \& Hartman ML. Sensitivity and specificity of six tests for the diagnosis of adult GH deficiency. Journal of Clinical Endocrinology and Metabolism $2002 \mathbf{8 7}$ 2067-2079.

15 Carroll PV, Monson JP, Grossman AB, Besser GM, Plowman PN, Afshar F \& Savage MO. Successful treatment of childhood-onset Cushing's disease is associated with persistent reduction in growth hormone secretion. Clinical Endocrinology 200460 169-174.

16 Storr HL, Afshar F, Matson M, Sabin I, Davies KM, Evanson J, Plowman PN, Besser GM, Monson JP, Grossman AB \& Savage MO. Factors influencing cure by transsphenoidal selective adenomectomy in paediatric Cushing's disease. European Journal of Endocrinology $2005152825-833$.

17 Johannsson G, Sunnerhagen KS \& Svensson J. Baseline characteristics and the effects of two years of growth hormone replacement therapy in adults with growth hormone deficiency previously treated for Cushing's disease. Clinical Endocrinology $200460550-559$.
18 Feldt-Rasmussen U, Abs R, Bengtsson BA, Bennmarker H, Barmnert M, Hernberg-Stahl E, Monson JP, Westberg B, Wilton P, Wuster C \& the KIMS international Study Board on behalf of the KIMS Study Group. Growth hormone deficiency and replacement in hypopituitary patients previously treated for acromegaly or Cushing's disease. European Journal of Endocrinology 2002146 67-74.

19 Hughes NR, Lissett CA \& Shalet SM. Growth hormone status following treatment for Cushing's syndrome. Clinical Endocrinology 199951 61-66.

20 van Aken MO, Pereira AM, Biermasz NR, van Thiel SW, Hoftijzer HC, Smit AJ, Roelfsema F, Lamberts SWJ \& Romijn J. Quality of life in patients after long-term biochemical cure of Cushing's disease. Journal of Clinical Endocrinology and Metabolism $2005903279-3286$.

21 Littley MD, Shalet SM, Beardwell CG, Ahmed SR, Applegate G \& Sutton ML. Hypopituitarism following external radiotherapy for pituitary tumours in adults. Quarterly Journal of Medicine 198970 145-160.

22 Magiakou MA, Mastorakos G, Gomez MT, Rose SR \& Chrousos GP. Suppressed spontaneous and stimulated growth hormone secretion in patients with Cushing's disease before and after surgical cure. Journal of Clinical Endocrinology and Metabolism 1994 78 131-137.

23 Kuwayama A, Kageyama N, Nakane T, Watanabe M \& Kanie N. Anterior pituitary function after transsphenoidal selective adenomectomy in patients with Cushing's disease. Journal of Clinical Endocrinology and Metabolism 198153 165-173.

24 Nakane T, Kuwayama A, Watanabe M, Takahashi T, Kato T, Ichihara K \& Kageyama N. Long-term results of transsphenoidal adenomectomy in patients with Cushing's disease. Neurosurgery $198721218-222$.

25 Mukherjee A, Murray RD, Teasdale GM \& Shalet SM. Acquired prolactin deficiency (APD) after treatment for Cushing's disease is a reliable marker of irreversible severe GHD but does not reflect disease status. Clinical Endocrinology $200460476-483$.

26 Growth Hormone Research Society. Consensus guidelines for the diagnosis and treatment of adults with growth hormone deficiency: summary statement of the Growth Hormone Research Society Workshop on Adult Growth Hormone Deficiency. Journal of Clinical Endocrinology and Metabolism 199883 379-381.

27 Giustina A, Bossoni S, Bodini C, Girelli A, Balestrieri GP, Pizzocolo G \& Wehrenberg WB. Arginine normalizes the growth hormone $(\mathrm{GH})$ response to $\mathrm{GH}-$ releasing hormone in adult patients receiving chronic daily immunosuppressive glucocorticoid therapy. Journal of Clinical Endocrinology and Metabolism 1992 $\mathbf{7 4 3}$ 1301-1305.

28 Ghigo E, Goffi S, Nicolosi M, Arvat E, Valente F, Mazza E, Ghigo MC \& Camanni F. Growth hormone $(\mathrm{GH})$ responsiveness to combined administration of arginine and GH-releasing hormone does not vary with age in man. Journal of Clinical Endocrinology and Metabolism 199071 1481-1485.

29 Magiakou MA, Mastorakos G, Zachman K \& Chrousos GP. Blood pressure in children and adolescents with Cushing's syndrome before and after surgical cure. Journal of Clinical Endocrinology and Metabolism 199782 1734-1738.

30 Mancini T, Kola B, Mantero F, Boscaro M \& Arnaldi G. High cardiovascular risk in patients with Cushing's syndrome according to 1999 WHO/ISH guidelines. Clinical Endocrinology 200461 768-777.

31 Colao A, Pivonello R, Spiezia S, Faggiano A, Ferone D, Filippella M, Marzullo P, Cerbone G, Siciliani M \& Lombardi G. Persistence of increased cardiovascular risk in patients with Cushing's disease after five years of successful cure. Journal of Clinical Endocrinology and Metabolism 199984 2664-2672.

32 Qu XD, Gonzalo ITG, Al Sayed MY, Cohan P, Christenson PD, Swerdloff RS, Kelly DF \& Wang C. Influence of body mass index and gender on growth hormone $(\mathrm{GH})$ response to GH-releasing hormone plus arginine and insulin tolerance tests. Journal of Clinical Endocrinology and Metabolism 200590 1563-1569. 
33 Carmichael JD, Danoff A, Milani D, Roubenoff R, Lesser ML, Livote E, Reitz RE, Ferris S \& Kleinberg D. GH peak response to GHRH-arginine: relationship to insulin resistance and other cardiovascular risk factors in a population of adults aged 50-90. Clinical Endocrinology 200665 169-177.

34 Pecori Giraldi F, Moro M, Cavagnini F \& the Study Group of the Italian Society of Endocrinology on the pathophysiology of the hypothalamic-pituitary-adrenal axis. Gender-related differences in the presentation and course of Cushing's disease. Journal of Clinical Endocrinology and Metabolism 200388 1554-1558.

35 Borges MH, DiNinno FB \& Lengyel AMJ. Different effects of growth hormone-releasing peptide (GHRP-6) and GH-releasing homone on $\mathrm{GH}$ release in endogenous and exogenous hypercortisolism. Clinical Endocrinology 199746 713-718.

36 Senaris RM, Lago F, Coya R, Pineda J \& Dieguez C. Regulation of hypothalamic somatostatin, growth hormone-releasing hormone, and growth hormone receptor messenger ribonucleic acid by glucocorticoids. Endocrinology 1996137 5236-5241.

37 Wehrenberg WB, Bergman PJ, Stagg L, Ndon J \& Giustina A. Glucocorticoid inhibition of growth hormone in rats: partial reversal with somatostatin antibodies. Endocrinology $19901272705-2708$.

38 Leal Cerro A, Soto A, Martinez MA, Álvarez P, Isidro L, Casanueva FF, Dieguez C \& Cordido F. Effect of withdrawal of somatostatin plus growth hormone (GH)-releasing hormone as a stimulus of $\mathrm{GH}$ secretion in Cushing's syndrome. Clinical Endocrinology 200257 745-749.

39 Procopio M, Invitti C, Maccario M, Grottoli S, Cavagnini F, Camanni F \& Ghigo E. Effect of arginine and pyridostigmine on the GHRH-induced GH rise in obesity and Cushing's syndrome. International Journal of Obesity and Related Metabolic Disorders $199519108-112$.
40 Webb SM, Rigla M, Wägner A, Oliver B \& Bartumeus F. Recovery of hypopituitarism after neurosurgical treatment of pituitary adenomas. Journal of Clinical Endocrinology and Metabolism $1999 \mathbf{8 4}$ 3696-3700.

41 Corneli G, Baldelli R, Di Somma C, Rovere S, Gaia D, Pellegrino M, Gasco V, Durante C, Grottoli S, Colao A, Tamburrano G, Lombardi G, Ghigo E \& Aimaretti G. Occurrence of GH deficiency in adult patients who underwent neurosurgery in the hypothalamus-pituitary area for non-functioning tumour masses. Growth Hormone and IGF Research $200313104-108$.

42 Hoeck HC, Bang F \& Laurberg P. Impaired growth hormone secretion in patients operated for pituitary adenomas. Growth Regulation 1994 4 63-67.

43 Di Somma C, Pivonello R, Loche S, Faggiano A, Klain M, Salvatore M, Lombardi G \& Colao A. Effect of 2 years of cortisol normalization on the impaired bone mass and turnover in adolescent and adult patients with Cushing's disease: a prospective study. Clinical Endocrinology 200358 302-308.

44 Colao A, Di Somma C, Spiezia S, Rota F, Pivonello R, Savastano S \& Lombardi G. The natural history of partial growth hormone deficiency in adults: a prospective study on the cardiovascular risk and atherosclerosis. Journal of Clinical Endocrinology and Metabolism 200691 2191-2300.

Received 14 September 2006

Accepted 6 November 2006 